\title{
Educational Evaluation of the Federal University of Latin American Integration, Brazil
}

\author{
Guillermo Javier Díaz Villavicencio (https://orcid.org/0000-0002-9455-1561) ${ }^{1^{*}}$ \\ 1 Federal University of Latin American Integration, Foz do Iguaçu - PR - Brazil \\ *Guillermo.diaz@unila.edu.br
}

\section{Submitted: 17/03/2020. Accepted: 04/04/2020}

Published: 09/04/2020

\begin{abstract}
Purpose: Analyzes satisfaction with the Federal University of Integration of Latin America (UNILA). Focused on the development of a new educational scheme in Latin America, being a university more open to change, multicultural, bilingual and Latin American.
\end{abstract}

Methodology: the institutional evaluation quantitative methodology would be applied by the multidimensional method, being able to contemplate all the specificities of the academic community.

Findings: This study answers four hypotheses that are within the four large educational dimensions evaluated. The results show that there are around $62 \%$ of satisfaction throughout the university, but they also indicate a concern for international, social and educational cooperation.

Research Limitation: The main limitation of the investigation is related to the period of time considered (one year). Therefore, it is recommended to verify the results obtained in this study, carrying out a longitudinal investigation (considering more years).

Originality: We generated a model that is oriented towards a generic measurement of satisfaction and it was builted considering the four distinguishing dimensions required by Educational Minister. All results were analyzed in a linear regression econometric model that were show us the level of significance of each question.

KEYWORD: multicultural education, evaluation technique, multidimensional analysis, regression econometric model, reliability and validity.

\section{Avaliação educacional da Universidade Federal de Integração da América Latina, Brasil}

\section{RESUMO}

Objetivo: Analisa a satisfação com a Universidade Federal de Integração da América Latina (UNILA). Focada no desenvolvimento de um novo esquema educacional na América Latina, sendo uma universidade mais aberta à mudança, multicultural, bilíngue e latino-americana.

Metodologia: a metodologia quantitativa da avaliação institucional seria aplicada pelo método multidimensional, podendo contemplar todas as especificidades da comunidade acadêmica.

Resultados: Este estudo responde a quatro hipóteses que estão dentro das quatro grandes dimensões educacionais avaliadas. Os resultados mostram que há cerca de $62 \%$ de satisfação em toda a universidade, mas também indicam uma preocupação com a cooperação internacional, social e educacional.

Limitação: A principal limitação da investigação está relacionada ao período de tempo considerado (um ano). Portanto, recomenda-se verificar os resultados obtidos neste estudo, realizando uma investigação longitudinal (considerando mais anos).

Originalidade: Geramos um modelo orientado para uma medida genérica de satisfação e foi construído considerando as quatro dimensões distintivas exigidas pelo Ministro da Educação. Todos os resultados foram analisados em um modelo econométrico de regressão linear que nos mostrou o nível de significância de cada questão.

PALAVRAS-CHAVE: educação multicultural, técnica de avaliação, análise multidimensional, modelo econométrico de regressão, confiabilidade e validade. 


\section{INTRODUCTION}

Satisfaction is one of the most important indicators to measure the quality of education within the universities. But this is, intimately, related to the level of general satisfaction of all people involved in the educational process (Jiménez, et al., 2011; Zas, 2002). Besides, in a large part of the countries, there are private and public universities with different market objectives which contributes to the complexity of the subject. Public universities that have different educational systems, do not escape the evaluation of the State and Society, we see it in the case of the Open University of Brazil UAB (Mendonca et al., 2020).

Pérez Zamora et al. (2012) carried out a study in Spain and identified that students from private universities feel more satisfied than those from public institutions. Although, he has highlighted that there are no significant differences between the two groups. Although student satisfaction with private universities scores higher in aspects of professional competencies and administrative service, public institutions score higher in relation to the university environment and the quality of the library. Flores Balboza (2005), argues that student satisfaction reflects the efficiency of various aspects involved in their daily educational experience, such as the level of difficulty of the course, the interaction with teachers and other students, the fairness in which they are evaluated, the facilities and teams that support these interactions.

The Federal University of Latin American Integration (UNILA) was created in 2010 in partnership with the Ministry of Education of Brazil (MEC). The philosophical and methodological principles of UNILA are formulated to guide teaching, research and extension practices, as well as university management in order to, Latin American and Caribbean themes, be explored with consistency. Those principles are interdisciplinarity, interculturality, bilingualism, multilingualism, solidary integration, democratic management, ethics, human rights, ethnic-racial-gender equity, sustainability and well-being.

It is maintained by the Federal State of Brazil and endowed with autonomy in its didactic, scientific, financial-patrimonial management, administrative and disciplinary. Currently, offer 29 undergraduate programs, 8 master, 1 doctorate in International Relations and 3 specialization courses.

The interculturality concept refers to the cultural diversity that manifests in today's society. If large cities are taken as reference, we will see people from different ethnic origins, languages and cultural traditions. To problematize the meanings and reinterpretations of students' identity, at the Federal University of Latin American Integration and its institutional proposal is to interest students from all over Latin America and the Caribbean to constitute to a multicultural space that promotes 
and develops devices for Latin American integration in different ways. The university is located in a city where its official media claims to be multicultural (THREE BORDERS).

In the construction of regional integration, UNILA values the dialogue and intercultural communication, the respect to the existing diversities, enable solidarity and legitimate construction, traditional knowledge and experiences, placing them in interaction with the various scientific and technological innovations; and a history of the differences and similarities between the cultures of the Latin American and Caribbean people.

Students identify themselves as "UNILEROS", formed between diachronic and synchronous temporality. The analysis of this process is based on the understanding that the students' paths in these relational spatialities were processed when they activated spaces of experiences and horizons of individual and social expectations, creating a temporal density that we have here as the object of the History of the Present Time.

The statute of UNILA was approved in 2012 and the General Regiment was approved in 2013. Within its Institutional Development Plan (PDI), the objectives of UNILA are to contribute to the solidarity integration of Latin America and Caribbean, through the construction and socialization of knowledge diversity necessary for the consolidation of fairer societies.

The institutional mission is to train human resources capable of contributing to integration, regional development and the cultural, scientific and educational exchange in the Latin America. The vocation of UNILA is the academic exchange and solidary cooperation with countries that are part of Latin America and Mercosur.

Within the public policies of Ministry of Education and Culture MEC, it is necessary to develop periodic, internal and external, evaluations of higher education institutions. The external one is carried out by a committee pointed by MEC and the National Institute of Permanent Evaluation (INEP). For the internal, a "Institutional Evaluation Commission" (CPA) is formed in each university to generate a mandatory and permanent evaluation.

The results pointed by CPAs should be oriented toward the reality of Institution and be a guiding instrument for planning and management of the university. It also meant questioning the meanings of the set of activities and purposes fulfilled by the institution; identify the causes of your problems and deficiencies; increase the pedagogical awareness and professional capacity of the university and the administrative technician; strengthen cooperative relations between the various institutional actors; make the institution's link with the community more effective; judge the relevance of your scientific / social activities and products; and be accountable to society, as recommended by the National Commission of Avaliação da Educação Superior CONAES (acronym in Portuguese) 
The two axes evaluated by CPAs are: Academic Policies and Physical Infrastructure. Among them, the following dimensions: policy for teaching; research; graduation; communication; student assistance policies; physical infrastructure; library; information and communication resources; extension and related operating norms, including procedures to stimulate academic production, research grants, monitoring and other modalities.

From 2010 to 2016, UNILA has carried out 6 institutional evaluation assessment reports with a series of basic descriptive indicators such as; number of students, teachers, administrative technicians in education (EAT), courses, etc. All reports delivered a large amount of information for a better decision making in the institution.

UNILA is the only bilingual university in Brazil and has almost 50\% of its students and teachers from 16 different nationalities. Seen that, it is necessary to know if the project of UNILA is satisfactory for the university community from the perspectives of academic policies, communication with society, student care and physical infrastructure. In this sense, we will seek to answer the posed question and propose a standardized evaluation model, through an inferential analysis of the latest survey applied by the 2016 CPA.

In our article, the measurement instruments of the sample that has been applied in 2016 are presented, the data is analyzed and discussed. The conclusions were drawn to propose a model and to see the level of satisfaction of the actors in the university community.

\section{The research Method}

The CPA agreed that the methodology of the institutional evaluation assessment would be applied by the multidimensional method, so can be contemplated all specificities of the multicultural and interdisciplinary reality of the academic community, defined as teachers, students and technicians. Other authors use the Dialectical Historical Materialism (MHD) as a measuring tool (Remolina-Caviedes, 2020). The choice of a multidimensional and multidisciplinary evaluative process contemplates all the theoretical suggestions of the evaluation in Higher Education field, as well as the philosophical principles of the Institutional Development Plan of UNILA (PDI).

Three survey models were used, one model for each category (Students, Professors and EATS - Administrative Technicians of Higher Education). The questions were divided according to the Dimensions of Policies for Teaching, Research and Extension in the PDI, Communication with society, Student Service Policies and Physical Infrastructure of UNILA.

Considering that we have longitudinal data for each of the applied surveys, where it will be analyzed the variable "satisfaction" of the interviewees in their different dimensions (where the dependent variable is continuous), we will examine the regression model by ordinary least squares for a base of longitudinal data. 
As such we can consider that and $y^{*}{ }_{i t}$ represents a censored sample (Novales, 1993, p.552) in a linear function of $\mathrm{K}$ explanatory variables $\left(\mathrm{x}_{\mathrm{k}}\right.$ where $\left.\mathrm{k}=1,2,3, \ldots, \mathrm{k}\right)$ :

$$
y *_{i t}=\beta_{0}+\beta_{1} x_{1 i t}+\beta_{2} x_{2 i t}+\ldots+\beta_{k} x_{k i t}+u_{i t}
$$

simpler:

$$
y^{*}{ }_{i t}=\beta_{0}+\sum_{k=1}^{k} \beta_{k} x_{k i t}+u_{i t}
$$

Where $\mathrm{i}=1, \ldots \mathrm{N}$ units and $\mathrm{t}=1, \ldots \mathrm{T}$ observations in the period; in matrix notation would be our econometric model:

$$
y^{*}{ }_{i t}=\beta_{k}^{\prime} x_{k i t}+u_{i t}
$$

Furthermore, $u_{i t}$ is also the error term that represents the effects of all other variables omitted from the model. That is, it is the observed variation of the dependent variable, and cannot get explained by the variation observed in the k independent variables. Expressions (1), (2) and (3)

are identical. The letters $\beta_{0} \beta_{1} \beta_{2} \ldots \beta_{k}$ are the parameters that need to be measured. $\beta_{0}$ is the intercept, the constant term; while the other parameters are the slopes of $y^{*}{ }_{i t}$ with respect to each of $\mathrm{K}$ independent variables.

For each category, we will apply a survey (summarized in Appendix 1) and generate a reliability analysis of the sample (Cronbach's Alpha) by resignation. Then, a linear regression analysis, by dimension, will be performed to determine the significance that the categories give to each question (see Fig. 1).

Based on Diaz-Villavicencio et al. (2016), that recommends a simple regression for each construct, four constructions (factor analysis) were generated with a regression for each Dimension/ Categories, considering the information of 5,110 surveys (Teachers, Students and EATS).

\section{Model Research and Hypothesis}

According to Sanchis et al. (2017), satisfaction is the result of a value process that occurs when a person expresses satisfaction or not with respect to something and makes a value judgment underpinned in the cognitive and affective (Gento \& Vivas, 2003). For Zas (2002), comments Sanchis et al. (2017), satisfaction refers to something or someone associated with what is wanted, expected and it is also related to a certain result.

This work aims answering if the UNILA actors are satisfied with the management. For this purpose, we generated a model that is oriented towards a generic measurement of satisfaction and it was builted considering the three categories and the four distinguishing dimensions required by MEC (see table 1). 
Table 1: Characterization of the dimensions.

\begin{tabular}{|c|c|}
\hline Dimension & Goals \\
\hline $\begin{array}{l}\text { 1. Policies for } \\
\text { Teaching, Research and } \\
\text { Extension. }\end{array}$ & $\begin{array}{l}\text { a) Formation of responsible graduate and committed to the search of } \\
\text { creative solutions for the equitable development of Latin America and } \\
\text { the Caribbean; } \\
\text { b) Articulation between all levels of education with the research and } \\
\text { extension activities, aiming the integral formation of the student; } \\
\text { c) Academic quality presented by the solid disciplinary and } \\
\text { interdisciplinary formation; } \\
\text { d) Appreciation of linguistic and cultural diversity of Latin America } \\
\text { and Caribbean; } \\
\text { e) Consideration of student as an active actor of the teaching-learning } \\
\text { process; } \\
\text { f) Plurality of theoretical and methodological ideas and conceptions; } \\
\text { g) Consistency among contents, teaching practices and the evaluation } \\
\text { process. (UNILA, 2013:26) }\end{array}$ \\
\hline $\begin{array}{l}\text { 2. Communication with } \\
\text { society }\end{array}$ & $\begin{array}{l}\text { General Objective: To contribute to the consolidation of UNILA, its } \\
\text { project, ideals and production of knowledge to legitimize them in Latin } \\
\text { American and Caribbean society. } \\
\text { Specific Objective 1: To disseminate the knowledge produced at the } \\
\text { University to objectify its mission. } \\
\text { Specific objective 2: To give visibility to the purpose of UNILA and its } \\
\text { differential, with the intention of disseminating the proposals for } \\
\text { integration at local, national, Latin American and Caribbean levels. } \\
\text { Specific objective 3: To promote the exchange of information and } \\
\text { dialogue between the different areas of UNILA, to achieve the } \\
\text { institutional mission. }\end{array}$ \\
\hline $\begin{array}{l}\text { 3. Student service } \\
\text { policies }\end{array}$ & $\begin{array}{l}\text { Objectives: 1) To expand the promotion of events and other } \\
\text { international academic activities in the Institution; 2) To regulate the } \\
\text { participation of university community in international events outside } \\
\text { UNILA, according to the annual plan; 3) Creation of mechanisms and } \\
\text { strategies to facilitate the academic and cultural cooperation, mobility } \\
\text { and integration among the universities of Latin American and } \\
\text { Caribbean countries, in the different areas of knowledge; 4) } \\
\text { Establishment of international agreements with all countries linked to } \\
\text { UNILA for the validation of issued diplomas by the university, thus } \\
\text { guaranteeing the possibility of professional recognition and functional } \\
\text { occupation in the countries of origin of the students; 5) Establishment } \\
\text { of institutional guidelines to follow the process of selecting foreign } \\
\text { students for undergraduate and graduate courses; 6) Permanent } \\
\text { orientation of foreign students, regarding their entry and stay in the } \\
\text { country, to the competent authorities. }\end{array}$ \\
\hline $\begin{array}{l}\text { 4. Physical } \\
\text { infrastructure }\end{array}$ & $\begin{array}{l}\text { General objective: to develop and appropriate the technologies of } \\
\text { information, to provide UNILA with access to information, specific } \\
\text { facilities and equipment that supply the institutional development. }\end{array}$ \\
\hline
\end{tabular}

All results were analyzed in a linear regression econometric model that will show us the level of significance of each question (see Fig. 1), from where a confirmatory factor analysis will be performed to determine the significance of each dimension with its category. 


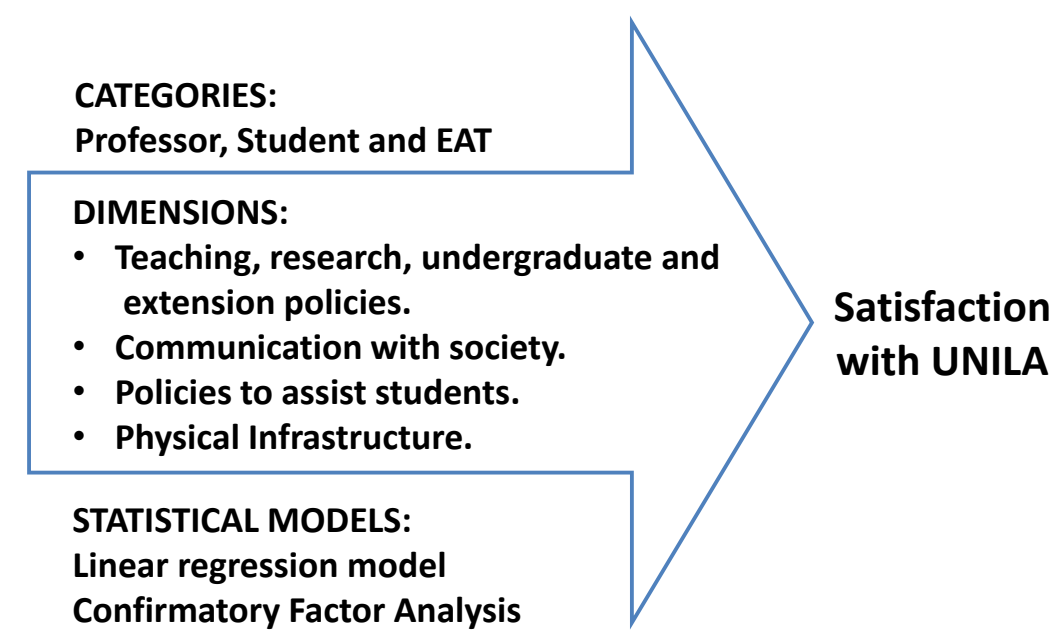

According to Sander (2007) educational management is guided by four principles of administration: effectiveness, efficiency, efficacy and relevance. Efficiency is characterized by the capacity of the institution to produce the maximum with the minimum of time, sources and energy, which makes this paradigm a tendency influenced by economic and productivist guidelines.

Students are the direct recipients of services provided by universities (public or private) and are considered the "main clients" of educational services (Crawford 1991; Wallace 1999; Douglas et al., 2006), since they are required to have a minimum of intellectual conditions for entrance or, in some cases, only enrolment fee (private universities). While students are interested in evaluating effectiveness, the university staff focus on both effectiveness and efficiency of services (De la Orden 1988; Bini \& Masserini, 2016). Additional research indicates that student satisfaction is a factor that affects student retention in universities, emotional distress and graduation rates are affected (Aitken 1982; Hatcher et al., 1992; Love, 1993). The quality of the university, learning environment, learning activities, tutoring and extracurricular activities influence the individual satisfaction of students and this generates opinions about the experience in the universities (Clark 2004; Jones 2009; Hussein \& Bahmani, 2012).

Beyond, the institutional evaluation assessment model imposed by the MEC, we can see that the analysis of "satisfaction" is a possible way to evaluate how a university is being efficient and fulfilling its mission (Ping, 1993).

Browne et al. (1998) emphasized that the perception of students about the quality of an academic institution is a precursor to their general satisfaction. To maintain the general satisfaction of students, universities must improve the perceived quality in classrooms (Misanew \& Tadesse, 2014). On the other hand, issues related to gender are not important when evaluating the satisfaction of a program in a university institution (Stables \& Kimbell, 2001). Therefore, the quality of educational services can be tested by evaluating general satisfaction of students. Assessing the 
perception of students and their expectations is therefore essential, particularly in a competitive context, since universities are being more oriented towards the needs of students and are expected to be responsible for the public funds received Bini and Masserini (2016).

Our study goes beyond the simple perception of students as object of study. We consider all actors involved in educational management and focus on the analysis of the three categories, which seek a level of efficiency in the services delivered. From the above, we can point out three related hypotheses to see the level of satisfaction in UNILA.

H1: There is a level of satisfaction generated on the average in the three categories.

H2: The result of the questions differs among categories.

H3: There are questions that identify more the three categories.

H4: There is a relationship of significance between categories and dimensions.

To answer those hypotheses, we have generated a descriptive and inferential analysis using a second step, the basic econometric model of multiple linear regression.

\section{Result and discussion}

This study involved a generic survey, differentiated for each of the four categories (Appendix 1) as indicated in the model (Fig.1). For the statistical analyzes the SPSS22 software was used.

The sample size is acceptable in all categories (exceeding a general minimum) at $95 \%$ confidence level with $+-5 \%$ sampling error. As the public to be surveyed is well known, a $p$ and $q$ of 0.25 (conservative) is assigned to obtain a minimum of acceptable responses to analyze if the interviewees were not known, a 0.50 in $p$ and $q$ would be required, which would involve a greater number of respondents. If the interviewees were not known, a 0.50 would be required, which would involve a greater number of respondents.

It should be considered that the surveys were conducted at the end of the year (in December 2016) and it was the first massive survey applied in UNILA, for this reason a great effort was necessary to spread the evaluation. The inquiry was conducted via Electronic, through the Integrated Academic Activities Management System (SIGAA), and it was answered by 273 students of 4,218, 97 teachers of 375 and 66 of 517 EATS. The questionnaire had the Likert scale from 1 to 7, where 1. Totally at odds, 2. Quite at odds, 3. Possibly at odds, 4. Neutral, 5. Agree, 6. Agree quite, 7. Totally agree and N/A. It does not apply. Other authors also use the Likert Scale to make evaluations of educational satisfaction, such as González et al. (2019).

We can see that the surveys, for each category, have a Cronbach's alpha with "high" means as shown by reliability analysis of the sample (Table 2). Considering a Cronbach's Alpha within the 
parameters of 0.4 - 0.6 (moderate) of 0.6-0.8 (good) 0.8-0.10 (high). In this sense, we can generate second degree analysis (inferential).

Table 2, Sample Reliability Analysis.

\begin{tabular}{lcrr} 
& \multicolumn{3}{c}{ Alfa of Cronbach } \\
\cline { 2 - 4 } Dimension/ Categories & Students & Teachers & EATS \\
\hline Policies of teaching, research, undergraduate programs and extension. &, 932 &, 874 &, 902 \\
\hline Communication with society. &, 944 &, 906 &, 919 \\
\hline Student Assistance Policies. &, 909 &, 885 &, 936 \\
\hline Physical Infrastructure. &, 933 &, 868 &, 925 \\
\hline ALL VARIABLES &, 974 &, 95 &, 964
\end{tabular}

The descriptive analysis of the sample indicates that the level of general satisfaction is $62 \%$ (Table 3). This shows that the level of satisfaction is above the average (50\%), what reflects that the three categories have a good level of satisfaction with everything that involves UNILA, thus responding to the hypothesis 1 .

Table 3. University Satisfaction Level

\begin{tabular}{lrrrc}
\hline Grouping by Trend: & Teachers & \multicolumn{1}{c}{ EATS } & \multicolumn{1}{c}{ Student } & \multicolumn{2}{c}{ Total } \\
\hline Unsatisfied (op. 1,2 and 3) & $25,8 \%$ & $10,5 \%$ & $12,5 \%$ & $16 \%$ \\
\hline It has no tendency (op. 4) & $16,5 \%$ & $16,7 \%$ & $16,5 \%$ & $17 \%$ \\
\hline Satisfied (op. 5, 6 and 7) & $53,6 \%$ & $69,7 \%$ & $62,3 \%$ & $\mathbf{6 2 \%}$ \\
\hline Do not respond & $4,1 \%$ & $3,0 \%$ & $8,8 \%$ & $5 \%$ \\
\hline & & & Total & $100 \%$ \\
\hline
\end{tabular}

In Table 4, we can see that there are a series of questions reflecting different significance within the regression analysis which is understood as questions that affect, directly and positively, the different categories. This answers hypothesis 2 , since the questions do not have the same significance as the questions that arise between the categories. It also answers hypothesis 3 , in which, if there are questions identifying the three categories (for our results would be the questions repeated as significant, questions 5,7,8 and 9) between the different dimensions, only 4 of 35 questions has a greater significance for the interviewees.

It draws attention to the dimensions 2 and 3 because of their low general significance for teachers and EATS, but the students have the most questions with common interests. Detailing the questions by dimension we have:

Dimension 1: 
P5_Professores and Students: The planning and execution of institutional actions (bilingual notices, institutional and academic documents, among others) meet the bilingual specificities of teachers, EATS and students.

P7_Professores and Students: UNILA has research policies (Scientific Initiation, Institutional Research Projects) that stimulate and support the development of actions.

P9_Students: The Ombudsman works according to clearly established quality standards.

P4_EATS: The planning and execution of institutional actions (bilingual notices, institutional and academic documents, among others) meet the bilingual specificities of teachers, EATS and students.

\section{Dimension 2:}

P7_EATS and Students: The actions that aim the relationship of UNILA with the external community are adequate and effective.

P5_Students: The UNILA website has updated information and easy location.

Dimension 3:

P5_Students: The software installed in the computer labs are sufficient to meet the teaching and research demands of the taken courses.

P2_Professors: The reception of freshmen informs adequately about the operation of UNILA.

\section{Dimension 4:}

P5_Professors: The software installed in the computer labs are sufficient to meet the teaching and research demands of the taught subjects.

P8_Professors and students: The e-mail, institutional website and SIGAA system provide technical assistance in the circulation of information and communication.

P9_Professors and students: The library buys and / or has the required books contained in the pedagogical project of the courses in sufficient quantity.

Table 4: Regression Questions.

\begin{tabular}{|c|c|c|c|c|c|c|}
\hline \multirow[t]{2}{*}{ Categories } & \multicolumn{2}{|c|}{ Professors } & \multicolumn{2}{|l|}{ EATS } & \multicolumn{2}{|l|}{ Students } \\
\hline & Questions & *Sig. & Questions & $*$ Sig. & Questions & *Sig. \\
\hline \multirow[t]{4}{*}{ Dimension 1} & P5 & 0,02 & P4 & 0,05 & P5 & 0,03 \\
\hline & P7 & 0,00 & & & P6 & 0,00 \\
\hline & & & & & P7 & 0,00 \\
\hline & & & & & P9 & 0,00 \\
\hline \multirow[t]{2}{*}{ Dimension 2} & & & P7 & 0,27 & P5 & 0,00 \\
\hline & & & & & P7 & 0,00 \\
\hline \multirow[t]{2}{*}{ Dimension 3} & P2 & 0,01 & & & P3 & 0,00 \\
\hline & & & & & P5 & 0,00 \\
\hline \multirow[t]{4}{*}{ Dimension 4} & P1 & 0,02 & P8 & 0,00 & P2 & 0,01 \\
\hline & P5 & 0,05 & & & P4 & 0,04 \\
\hline & P8 & 0,01 & & & P8 & 0,00 \\
\hline & P9 & 0,00 & & & P9 & 0,01 \\
\hline
\end{tabular}


It can be observed on teachers' category, in Table 5, that only dimension 1 is significant. This indicates that the themes of teaching, research, graduate programs and extension policies have a great influence on satisfaction of professors, but the other three dimensions are not significant to them. Which replaces the hypothesis 4 regarding the existence of a relationship between dimensions and categories with different levels of significance.

Table 5: Confirmatory Factorial Analysis

\begin{tabular}{|c|c|c|c|c|c|c|c|c|}
\hline Categories & \multicolumn{2}{|c|}{ Dimension 1} & \multicolumn{2}{|c|}{ Dimension 2} & \multicolumn{2}{|c|}{ Dimension 3} & \multicolumn{2}{|c|}{ Dimension 4} \\
\hline Teachers & $\begin{array}{l}\text { B } \\
0,976\end{array}$ & $\begin{array}{l}* \text { Sig. } \\
.00\end{array}$ & B & $*$ Sig. & B & *Sig. & B & $*$ Sig. \\
\hline EATS & & & & & & & 0,687 & .00 \\
\hline Students & 0,782 & .00 & 0,493 & .00 & & & 0,491 & .00 \\
\hline
\end{tabular}

In the EATS category only Dimension 1(Physical Infrastructure) is significant, what relates to the null concern of EATS for academic and formation issues. In a satisfactory way, we can argue that the level of satisfaction with UNILA by the students is highly favorable, since 3 of the 4 dimensions are significant. Only the dimension (student attendance policies) is not significant, therefore, they do not influence the overall satisfaction of the students.

\section{Conclusion}

This article aims to detail the satisfaction level of students, professors and EATS with the university. UNILA is the first internationalized Latin American University that participates in an innovative educational project in which its Higher Education programs intent to contemplate exchanges with the Latin America countries and create a cultural cooperation. Being a transnational university, it integrates a larger repertoire of contributions that Brazilian State desires to promote so that Latin America can grow beyond than merely economic.

Therefore, we must consider that UNILA is changing a scientific paradigm in the Latin American studies. When, in eight years, it has produced knowledge about its own categories and actors. Before UNILA foments the regional studies in Latin America, those were restricted to the borders of disciplinary fields in other Latin American countries and their work used to circulate with great difficulty in Brazil. The Americanist centers are based on the idea that the Latin America are not able to produce knowledge about itself because it is at a lower level of development. The project of a University for the Latin American society breaks with this orientalist paradigm and fosters a proposal based on the unique and formative characteristics of Latin America, as one day 
dreamed Octavio Paz: Will we now be able to think for ourselves? Can we conceive a model of development that is our version of modernity?

With those words, the Mexican writer discusses the necessity that Latin America had to conceive a project of proper modernity from our historical and social experience. This questioning marked the entire generation of literary critics. Writers like Octavio Paz are contemplated in the project to create UNILA, because this University prioritizes the intercultural knowledge. The international and cosmopolitan dimension of UNILA stands out when it receives students from all socioeconomic regions of Latin America, even from ethnic communities. Thus, the encounter of cultural diversity at the University, endorses cultural dialogue as an element to produce knowledge and cooperation capable of generating a solidary integration.

In this scenario the institutional evaluation plays a fundamental role through the CPA and from our analyzes we can say that the institution meets the objectives setting. We also reinforce that UNILA reaches a $62 \%$ general acceptance (satisfaction) of the three categories by checking the four raised hypotheses, since that there is a level of satisfaction on the average in the three categories (H1), denoting that the result of the question differs between categories $(\mathrm{H} 2)$, that there are questions that identify more to the three categories $(\mathrm{H} 3)$ and that there is a relation of significance between categories and dimensions (H4). All of this reflects the wide range of differences that UNILA has, and which makes it a diverse, pluralist and Latin American university.

Following the 2016 report, it is recommended for the benefit of Education, Research, Graduate and Extension policies, the joint planning between teaching and pro-rector units, professor training for bilingual and intercultural education, integration of graduate programs and undergraduation activities, support for teaching projects developed by teachers of the Common Cycle, the expansion of monitoring and mentoring programs, greater availability of resources for research and group activities, the Research Pro-rectory restructuring to better serve the Research Department, the creation of more research laboratories, the provision of more space for the extension, resources and accreditation of extension activities in the curricular norms of graduation.

As for the Communication Dimension with society, it is suggested to increase the flow of information between academic and administrative units, to improve communication with the external local community and with the international external community belonging to the Latin American countries, the dissemination of scientific promotion forms, the strengthening of the ombudsman as mediator between agents of the internal community. It is also necessary to point out that the communication area is responsible for captain the actions about the University institutional communication policy, observing the established goals fulfillment in the PDI 2013-2018. In relation to Student Assistance, it is recommended to make possible the service expansion and the articulation between the Pro-Rectory of Student Affairs (PRAE) and teaching units, as well as to 
retake the execution of specific projects, such as the support and pedagogic accompaniment project for students. Finally, it is recommended to rethink the role of the Pro rectory extension PRAE in processes and administrative flows. For the physical infrastructure dimension, it was possible to observe that it has accompanied the University growth in a poorly orderly manner, having a good assistance in the IT configuration of the Information Technology equipment. Therefore, the major challenge is to develop a strategic institutional planning for the own buildings construction, resulting in a master plan of infrastructure. That said, the CPA warns that UNILA has not yet developed any planning actions to solve the institution's imminent lack of physical space, posing a clear risk for the University.

With respect to the institutional mission and the PDI norms for the analyzed dimensions, UNILA is coherent. However, the low enrollment of international students in undergraduate and graduate courses can put the feasibility of integrative mission at risk. To avoid this scenario, the CPA advises UNILA to carry out an institutional research on the conditions of reception, welcoming and adaptation of international students, as well as the reasons for the university dropout of these students. In addition, it is recommended to increase the information flows of notices dissemination about the international selection for undergraduate and graduate courses and to review the selection process of international students and standards for professor selection, as the proportionality between international and Brazilians teachers is also lower than expected in the PDI.

\section{Limitations and future research}

The main limitation of the present investigation is related to the time analyzed (a single period). Therefore, it is recommended to verify the results obtained in this study, carrying out a longitudinal investigation considering a longer analysis time.

There is no successful evidence of this type of project in the university, which has made it difficult to make a comparative analysis of whether the evaluation is consistent with other university experiences. What is found in the literature are the splendor of traditional Universities that are internationalized, which is not the case of UNILA, because UNILA is a creation under the parameter of internationalization from the beginning.

Future studies may add social type variables (non-formal relationships) between student and teacher and Education Administrative Technicians EAT and teacher, to see if informal factors influence the general results. In the same way, see the international immigration laws that affect the assessment for UNILA. 


\section{References}

Aitken, N. (1982). College student performance, satisfaction, and retention: Specification and estimation of a structural model. Journal of Higher Education, 53(1), 32-50. https://doi.org/10.1080/00221546.1982.11780423

Amaral, E., Gonçalves, E., Potter, J. (2012). Long Term Influences of Age-Education Transition on the Brazilian Labour Market. Bulletin of Latin American Research, 31(3), 302-319. https://doi.org/10.1111/j.14709856.2011.00642.x

Bini, M., Masserini, L. (2016). Students's satisfations and teaching efficiency of university offer. Social Indicators Research, 129, 847-862. https://doi.org/10.1007/s11205-015-1141-0

Browne, B., Kaldenberg, D., Browne, W., Brown, D. (1998). Student as customers: Factors affecting satisfaction and assessments of institutional quality. Journal of Marketing for Higher Education, 8(3), 1-14. https://doi.org/10.1300/j050v08n03_01

Remolina-Caviedes J.F. (2020). Evaluación educativa y codeterminaciones de la producción escolar Ensaio: avaliação política pública Educação, 28(106), 135-155. https://doi.org/10.1590/S0104-40362019002701629

Clark, B. R. (2004). Sustaining change in universities: Contingencies in case studies and concepts. Berkshire: England. Cpa Comissão Própria de Avaliação. (2016). Relatório parcial de auto avaliação institucional II. CICLO 2016. UNILA. https://unila.edu.br/sites/default/files/files/II_Relat\%C3\%B3rio_de_Autoavaliacao_CPA\%20-

$\% 20$ CICLO $\% 202016(1)$.pdf

Crawford, F. (1991). Total quality management. London: Committee of vice-chancellors and principals occasional paper of the universities of the United Kingdom.

De La Orden, A. (1988). La calidad de la educación. Bordón, 40(2), 149-161.

Diaz-Villavicencio, G., Didonet, S., Dodd, A. (2016). Perspectives on Innovation Management of Ecuadorian Companies, International Journal of Innovation Management, 20(6), 1650048 (20 pages) @ World Scientific Publishing Europe Ltd. https://doi.org/10.1142/s1363919616500481

Douglas, J., Douglas, A., Barnes, B. (2006). Measuring student satisfaction at a UK university. Quality Assurance in Education, 14(3), 251-267. https://doi.org/10.1108/09684880610678568

Flores Balboza, J. (2005). Encuesta sobre la Satisfacción Estudiantil. Edit Lima.

Gento, S., Vivas, M. (2003). El SEUE: un instrumento para conocer la satisfacción de los estudiantes universitarios con su educación. Acción Pedagógica, 12(2), 16-27.

González S.S., Martin S.C., Gonzales M.C. (2019). Ensaio: aval. pol. públ. Educ., Rio de Janeiro, 27(105), 817-838. Doi: https://doi.org/10.1590/S0104-40362019002701625

Hatcher, L., Kryter, K., Prus, J. S., Fitzgerald, V. (1992). Predicting college student satisfaction, commitment, and attrition from investment model constructs. Journal of Applied Social Psychology, 22(16), 1273-1296. https://doi.org/10.1111/j.1559-1816.1992.tb00950.x

Hussein, N., Bahmani, S. (2012). Development of the student university satisfaction scale: Reliability and validity. Interdisciplinary Journal of contemporary research business, 4(3), 332-341.

Jiménez, A., Terriquez, B., Robles, F. (2011). Evaluación de la satisfacción académica de los estudiantes de la Universidad Autónoma de Nayarit. Revista Fuente, 3(6). https://doi.org/10.20937/rica.2019.35.esp02.02

Jones, S. (2009). Dynamics social norms and the unexpected transformation of women's higher education. Social Sciences History, 33(3), 247-291. https://doi.org/10.1215/01455532-2009-001

Love, B. J. (1993). Issues and problems in the retention of Black students in predominately White institutions of higher learning. Equity \& Excellence in Education, 26(1), 27-37. https://doi.org/10.1080/1066568930260105 
Mendonca, J., Fernandes, D., Helal, D., Cassunde, F. (2020). Políticas Públicas para la Educación Superior a Distancia: un examen del papel de la Universidad Abierta de Brasil. Ensaio: aval.pol.públ.Educ. [online], 28(106), 156-177. Epub 02-Dez-2019. https://doi.org/10.1590/s0104-40362019002801899

Misanew, A., Tadesse, M. (2014). Determinants of student and staff satisfaction with services at Dilla University, Ethiopia: Application of single and multilevel logistic regression analyses. Social Indicators Research, 119(3), 15711587. https://doi.org/10.1007/s11205-013-0561-y

Novales, A. (1993). Econometría. 2nd Edition. Interamericana de España, Madrid: McGraw-Hill.

Paz, O. (1976). O Labirinto da Solidão e Post-scriptum. trad. port., Rio de Janeiro: Paz e Terra.

Pérez Zamora, L.A., López López, M.C., Couto Olivares, J.M., Navarro Luque, G. (2012). Does student satisfaction depend on the actual quality of the faculty or on the perception of the student? comparative analysis between public and private faculties. ReiDoCrea. Revista electrónica de investigación Docencia Creativa. 1, 29-37.

Ping, C. (1993). Accountability in higher education. The Ohio CPA Journal, 52(2), 11-18.

Sanchis, C., Santana, R., Mora, M. (2017). Satisfacción de los estudiantes universitarios en los procesos de e-evaluación del aprendizaje. Actas xviii congreso internacional de investigación educativa interdisciplinariedad y transferencia aidipe.

Sander, B. (2007). Administração da Educação no Brasil: Genealogia do Conhecimento. Brasília: Liber Livro.

Stables, K., Kimbell, R. (2001). Technology education in south Africa: evaluating an innovative pilot project. Research in Science Education, 31, 71-90.

Wallace, J. (1999). The case for students as customers. Quality Progress, 32(2), 47-51.

Zas, B. (2002). La satisfacción como indicador de excelencia en la calidad de los servicios de salud. Revista Electrónica Psicología Científica. https://doi.org/10.1016/s1134-282x(01)77420-9 


\section{Appendix 1 (survey)}

Survey by Dimensions - Students (similar survey for teachers and EATS). 2016-2.

\section{Dimension 1: Teaching, research, graduation and extension policies.}

P1 Institutional actions for teaching, research and extension contribute to the integration of Latin America.

P2 The activities of tutoring and "monitoring" are adequate for the learning and use of the subjects.

The activities of "monitoring" and tutoring can face the linguistic and cultural difficulties that impede the

P3 understanding of the classes.

P4 UNILA, regularly, offers help to carry out the purposes of teaching, research and extension.

P5 The planning and execution of institutional actions (bilingual regulations, institutional and academic documents,

among others) meet the specifications of the teachers, and the students and technicians (EATS).

P6 The teaching activities of UNILA are planned to effectively respond to students in a multicultural and bilingual way.

$\mathrm{P} 7$ development of actions.

P8 The UNILA extension actions are close to the external community.

\begin{tabular}{l|l}
\hline P9 & The common cycle fosters the practice of integration studies in Latin America.
\end{tabular}

P10 The "Pro-rectory of research and graduate programs" has a policy and academic incentive programs for the "graduate programs".

\section{Dimension 2: Dimension: communication with society}

\begin{tabular}{l|l} 
P1 & Institutional email is sufficient to meet the needs of students.
\end{tabular}

P2 $\quad$ Internal information flows correctly.

P3 The dissemination of knowledge for the society that is produced in UNILA is carried out in a satisfactory way.

P4 The channels of communication used by UNILA (website, e-mail, magazines, information boards, social profiles) are effective.

P5 The UNILA website has updated and easily accessible information.

P6 Internal communication tools (e-mail, web page, "Unilera" Week, Service Bulletin) are adequate to meet the needs of students.

P7 Actions that seek the insertion of UNILA in the external community are appropriate and effective.

P8 The communication policy is adequate for the objectives settled in the PDI (Institutional Development Plan).

P9 The defender office works according to clearly established quality standards.

P10 The communication flows between the academic and administrative units are integrated.

Dimension 3: Policies for student assistance.

P1 $\quad$ The student attendance policy allows students to remain in UNILA.

P2 The reception of the first-year students adequately informs about the functioning of UNILA.

P3 The pedagogical / academic support offered by UNILA, through PROGRAD, satisfies the needs of its students. 


\begin{tabular}{|c|c|}
\hline P4 & $\begin{array}{l}\text { The Support Service for people with special needs and the Accessibility core plans and implements strategies } \\
\text { that ensure access, integration and permanence of students with special needs in the courses. }\end{array}$ \\
\hline P5 & $\begin{array}{l}\text { Housing, food and transportation programs are effective and manage to serve the students who need it (socio- } \\
\text { economic vulnerability). }\end{array}$ \\
\hline P6 & $\begin{array}{l}\text { The service provided by PRAE (social, psychological and health) contributes to the permanence of students who } \\
\text { need it (socioeconomic vulnerability). }\end{array}$ \\
\hline \multicolumn{2}{|c|}{ Dimension 4: Physical Infrastructure. } \\
\hline $\mathrm{P} 1$ & The administrative space is broad and adequate to meet the needs of students. \\
\hline $\mathrm{P} 2$ & $\begin{array}{l}\text { The infrastructure of the class has the necessary tools (projector, tables, air conditioning, lighting, furniture) for } \\
\text { the activities that are developed. }\end{array}$ \\
\hline P3 & $\begin{array}{l}\text { The auditorium and coexistence spaces (bars, cafeteria, courtyards) are sufficient to satisfy the demands of the } \\
\text { teaching and the academic community. }\end{array}$ \\
\hline P4 & $\begin{array}{l}\text { Computer labs have sufficient infrastructure (computers, furniture, air conditioning) to meet the demands of } \\
\text { teaching and research subjects studied. }\end{array}$ \\
\hline P5 & $\begin{array}{l}\text { The software installed in the computer labs is sufficient to meet the demands of teaching and research of the } \\
\text { subjects studied. }\end{array}$ \\
\hline P6 & The teaching laboratories have the necessary infrastructure for the classes and accommodate the academics. \\
\hline P7 & $\begin{array}{l}\text { The research laboratories have the necessary infrastructure for the development of the research together with the } \\
\text { guidance teachers. }\end{array}$ \\
\hline P8 & $\begin{array}{l}\text { The electronic mail, institutional website, SIGAA system attends to the circulation of information and } \\
\text { communication. }\end{array}$ \\
\hline P9 & $\begin{array}{l}\text { The library counts and provides in sufficient quantity the obligatory bibliography and suggestion that appears in } \\
\text { the programs of the subjects. }\end{array}$ \\
\hline \multicolumn{2}{|c|}{ Satisfaction with UNILA. } \\
\hline PX & In general terms, what is your level of satisfaction with UNILA? \\
\hline
\end{tabular}

\section{Note:}

- The author is an advisory member of the Own Evaluation Committee, Comissão Própria de Avaliação - CPA / UNILA, and has formal authorization to publish the data.

- The author thanks CPA for helping in this Work.

- This paper is part of the research group in Innovation, Efficiency and Environmental Management of Rural Development / Area: Urban and Regional Planning / CNPq Brazil. The paper is considered to be funded by the UNILA Project, PRPPG Nº 110. 